\title{
Prevalence and Patterns of Sugar-Sweetened Beverage Consumption in Canadian Youth: A Northern Focus
}

\author{
Laura E. Davis ${ }^{1}$ and Colleen M. Davison ${ }^{1,2}$
}

(Received 14 September 2016; accepted in revised form 25 July 2017)

\begin{abstract}
Regular consumption of sugar-sweetened beverages (SSBs) is a well-known risk factor for weight gain, tooth decay, and metabolic syndrome. Rates of SSB consumption in Nunavut specifically, have been noted to be exceptionally high. This study describes consumption rates of specific foods and beverages, with a focus on SSBs, among adolescents in Nunavut, northern Canada as a whole, and the Canadian provinces, using data from the 2010 and 2014 cycles of the Health Behaviour in School-aged Children (HBSC) study to investigate population characteristics and consumption patterns. Comparative analyses of consumption patterns for Nunavut, the three territories combined, and the southern provinces found that in 2010, those who consumed SSBs once a day or more comprised $53.1 \%$ of adolescents in Nunavut, $31.1 \%$ in the northern territories and $24 \%$ in the provinces. Comparable figures for 2014 were $55.0 \%$ in Nunavut, but only $27.0 \%$ in all the territories, and $19.1 \%$ in the provinces. The percentage of adolescents who consumed fruit and vegetables daily was also lower in Nunavut than in the provinces $(65.5 \%$ vs. $85.3 \%$ in 2010 , and $57.5 \%$ vs. $84.4 \%$ in 2014). More Nunavut adolescents consumed sweets and potato chips daily than provincial adolescents ( $42.6 \%$ vs. $27.6 \%$ in 2010 , and $52.2 \%$ vs. $25.2 \%$ in 2014). A greater proportion of Nunavut adolescents reported high consumption of SSBs, as well as other energy-dense foods, when compared to adolescents in the three territories combined and in the provinces. These results confirm previous studies but provide a current and comprehensive analysis that can help inform future food and nutrition priorities and programing.
\end{abstract}

Key words: Nunavut; Canada; North; youth; adolescents; beverages; sugar; eating habits; physical activity; screen time

RÉSUMÉ. La consommation régulière de boissons édulcorées est un facteur de risque bien connu pour le gain de poids, les caries et le syndrome métabolique. Au Nunavut plus particulièrement, la consommation de boissons édulcorées est exceptionnellement élevée. Cette étude décrit les taux de consommation d'aliments et de boissons spécifiques et met l'accent sur les boissons édulcorées chez les adolescents du Nunavut, du Nord canadien dans son ensemble, et des provinces canadiennes en s'appuyant sur les données des cycles de 2010 et de 2014 de l'enquête «Les comportements de santé des jeunes d'âge scolaire » (l'Enquête HBSC), enquête qui a pour but d'étudier les caractéristiques de la population et les habitudes de consommation. Les analyses comparatives des habitudes de consommation du Nunavut, des trois territoires dans leur ensemble et des provinces du sud du pays ont permis de remarquer qu'en 2010, 53,1\% des adolescents du Nunavut consommaient des boissons édulcorées une fois par jour ou plus, $31,1 \%$ dans les territoires du Nord et $24 \%$ dans les provinces. Pour 2014, les données comparables étaient de 55,0\% au Nunavut, mais de seulement 27,0\% dans l'ensemble des territoires et de 19,1 \% dans les provinces. Le pourcentage d'adolescents qui consommait des fruits et des légumes au quotidien était moins élevé au Nunavut que dans les provinces $(65,5 \%$ par opposition à $85,3 \%$ en 2010 , et $57,5 \%$ par opposition à $84,4 \%$ en 2014 ). $\mathrm{Au}$ Nunavut, un plus grand nombre d'adolescents consommait des sucreries et des croustilles au quotidien par rapport aux adolescents des provinces (42,6\% par opposition à $27,6 \%$ en 2010, et 52,2 \% par opposition à $25,2 \%$ en 2014). Une plus grande proportion d'adolescents du Nunavut a signalé une grande consommation de boissons édulcorées et d'autres aliments à forte teneur en énergie comparativement aux adolescents des trois territoires dans leur ensemble et aux adolescents des provinces. Ces résultats confirment les résultats d'études antérieures, en plus de présenter une analyse actuelle et exhaustive dont on peut se servir pour jeter de la lumière sur les priorités et la programmation futures en matière d'alimentation et de nutrition.

Mots clés : Nunavut; Canada; Nord; jeunes; adolescents; boissons; sucre; habitudes alimentaires; activité physique; temps passé à l'écran

Traduit pour la revue Arctic par Nicole Giguère.

\footnotetext{
${ }^{1}$ Queens University, Carruthers Hall, 62 Fifth Field Company Lane, Kingston, Ontario K7L 3N6, Canada

${ }^{2}$ Corresponding author: davisonc@queensu.ca

(C) The Arctic Institute of North America
} 


\section{INTRODUCTION}

Regular consumption of sugar-sweetened beverages (SSBs) such as soft drinks, sweetened juices, sports drinks, and energy drinks are well-known risk factors for weight gain, tooth decay, and metabolic syndrome leading to diabetes (Vartanian et al., 2007; Hu and Malik, 2010; Danyliw et al., 2012; Malik et al., 2013; Te Morenga et al., 2013; Bernabé et al., 2014). In this study, SSBs are defined as beverages that contain added caloric sweetener, such as sugar, highfructose corn syrup, and fruit juice concentrates ( $\mathrm{Hu}$ and Malik, 2010). Diet soft drinks and fruit juices without added sugar are not included.

High levels of SSB consumption are a serious public health concern in Canada (Public Health Agency of Canada, 2011; Lobstein, 2014). Currently, although prevalence rates for SSB consumption are known for the provinces, there is less available information for Nunavut and the territories (Garriguet, 2008a, b). Existing studies on consumption rates in Nunavut indicate they are very high. For example, Sheehy et al. (2013) found that $82 \%$ of adults in Nunavut regularly consumed two standard $335 \mathrm{ml}$ cans of soft drink per day. In contrast, $47 \%$ of males and $27 \%$ of females in southern parts of Canada consume SSBs daily (Garriguet, 2008b). Although there are some data on consumption patterns for adults and very young Inuit populations, little information is available on the dietary habits of school-aged Inuit youth, specifically with respect to SSB consumption, in Nunavut (Gates et al., 2014). This knowledge gap is important. Inherent health risks associated with SSB consumption in young people are significant, and reports from local communities in these regions indicate potentially alarmingly high rates of consumption.

Nunavut is Canada's largest territory, covering approximately two million $\mathrm{km}^{2}$. It houses 28 small remote, fly-in communities and accounts for nearly half of the total Inuit population in Canada, with Inuit representing more than $85 \%$ of the total population in the territory (Nunavut Bureau of Statistics, 2011; Statistics Canada, 2011). As a region, Nunavut has high rates of several risk factors for high SSB consumption. One is that many families in the territory deal with high levels of poverty; $17.2 \%$ of the population is unemployed, compared to the national average of $7.1 \%$ (Egeland et al., 2010a, b). Nunavut has the lowest average family income in Canada (Government of Nunavut, 2015; Statistics Canada, 2016). Child food insecurity in Nunavut is higher than the national average; recent estimates show that $70 \%$ of children in Nunavut live in food insecure households as compared to a national average of 17.2\% (Health Canada, 2007; Egeland et al., 2010b). Low socioeconomic status (SES) and factors associated with poverty have been linked to high SSB consumption (Mazarello Paes et al., 2015). Residents of Nunavut may be at increased risk of SSB consumption because of high rates of poverty and other indicators of low SES.

Nunavut residents also face high rates of negative health outcomes associated with SSB consumption, such as obesity and tooth decay. Obesity rates in the territory are estimated at approximately $26 \%$ for Nunavummiut children (Public Health Agency of Canada, 2011). Poor oral health, especially among children, has also been highlighted recently as an important public health issue in Nunavut (Houde et al., 1991; Lawrence et al., 2004; Schroth et al., 2009; Pacey et al., 2010). Studies have shown that $69.1 \%$ of children in Nunavut have either decaying, filled, or extracted teeth, compared to $57 \%$ of Canadian children overall (Health Canada, 2010; Pacey et al., 2010).

The aim of this study is to describe current patterns of food and beverage consumption, with a focus on SSBs, in Nunavut, the territories combined, and the provinces.

\section{METHODS}

\section{Study Population and Procedures}

This study uses Canadian data from the Health Behaviour in School-aged Children Study (HBSC). We obtained participant information for all regions of Canada from the 2010 and 2014 cycles of the survey. The Canadian HBSC survey is a nation-wide self-report survey within a larger international study, affiliated with the World Health Organization (WHO), that focuses on adolescent health. HBSC uses a multi-stage, cluster sampling strategy. First, schools are selected, followed by individual classrooms. All students in the selected classrooms are asked to participate. Each school requires either passive or active parental consent depending on local school board policy. In addition to those students who do not provide consent, students from private schools, home schools, young people living in First Nations reserves, and incarcerated youth, as well as other young people not at school on the day of the survey, are excluded from the survey.

In 2010, the Canadian HBSC reported on 26078 students from 436 schools and in 2014, it included 30117 students from 377 schools across Canada. In the 2010 cycle, all provinces and territories participated except New Brunswick and Prince Edward Island. The 2014 cycle included all 13 provinces and territories. The school response rate was $57 \%$ in 2010 and $50 \%$ in 2014, while the student response rate was 77\% in both 2010 and 2014 . This study stratifies adolescents by Nunavut students exclusively, "northern" students from the three territories collectively, and students from the 10 provinces.

Community characteristics were determined using additional sources of data. Community population, defined as the population in a $1 \mathrm{~km}$ buffer around the school, was determined using the census subdivision level data in the 2006 Canadian census (Statistics Canada, 2011). Road access was determined using geographic data and Google maps. The Northwest Territories Statistics Bureau was used to determine winter road access for northern communities. Soft drink prices were determined using the food price survey from Statistics Canada, as well as individual food 
price surveys from the statistics bureaus of Yukon, the Northwest Territories, and Nunavut (Jeff Barichello, NWT Bureau of Statistics, pers. comm. 2015; Nunavut Bureau of Statistics, 2015; Statistics Canada, 2015; Fraser Dametto, Yukon Bureau of Statistics, pers. comm. 2015).

\section{Measures}

Demographic characteristics included are sex (boys vs. girls), age, and grade in school (6-10). Family affluence was measured using the HBSC Family Affluence Scale. Data for Nunavut for this scale were available only for 2010. The Family Affluence Scale is a composite (four-question) measure of a student's level of wealth, which places each student in a category of high, medium, or low affluence. Questions for both years include whether or not the student has his or her own bedroom, the number of cars, vans or trucks the family owns, how many vacations outside of the country the student has been on in the past year, and the number of computers in the student's home. This item has been found to have a Kappa agreement coefficient of 0.57 with country GDP, indicating moderate validity (Boyce et al., 2006; Currie et al., 2008; Schnohr et al., 2008).

Physical activity was measured using two questions that assess the number of days the student was physically active in one week. Students were asked on how many days they were physically active for at least 60 minutes a) in a usual week and b) in the past week. These two items were then averaged to form an activity measure of days per week the student was physically active for at least 60 minutes. This measure was dichotomized as either meeting the guidelines for adolescent physical activity (60 minutes, 7 days a week) or not, as outlined by the Canadian Society for Exercise Physiology (Canadian Society for Exercise Physiology, 2012a). This method for measuring physical activity has been previously tested for reliability $(\mathrm{k}=61 \%)$ (Prochaska et al., 2001).

The screen time queries asked students to report on three behaviours: 1) watching television, videos, and DVDs, 2) playing games on a computer or console (Playstation, Xbox, Gamecube, etc.), and 3) using a computer for online chats, Internet, e-mail, homework, or other tasks. Responses ranged from "none at all" to "about 7 or more hours a day." To calculate the screen time measure, we first averaged the responses for each behaviour individually, then summed the averages for all three to obtain overall hours of screen time per day. This method has previously been tested for reliability against a seven-day log and has proven reliable (Schmitz et al., 2004). Responses were dichotomized as more than or equal to 2 hours a day and less than 2 hours a day, according to the Canadian guidelines for sedentary behavior (Canadian Society for Exercise Physiology, 2012b).

BMI was measured using student self-reported information on height and weight and was calculated using the standard formula: weight in kilograms divided by height in meters squared. One obvious extreme outlier was deleted. BMI was categorized into four categories: underweight, normal weight, overweight or obese. This was in accordance with the WHO's growth chart for boys and girls under 18 years of age (WHO, 2015).

The variables grandparents in the home and family structure were constructed using the question: "All families are different and we would like to know about yours. Please answer for the home where you live all or most of the time and mark the people who live there." Response options available were: mother, father, stepmother, stepfather, grandmother, grandfather, I live in a foster home or children's home, and with someone else. Students were categorized as living with their grandparents if they selected any combination that included either the grandmother and/or the grandfather and as having a nuclear family if they indicated that both their mother and father lived in the same home.

Family meals were measured slightly differently in the 2010 and 2014 survey cycles. In both cases a single question was used to determine how many days a week the student had an evening meal with their family. In 2010 the question asked: "On average, how many times per week does your family sit down at the table together for dinner/supper?" Responses ranged from 0 to 7 days a week. In 2014 the question asked: "How often do you have an evening meal together with your mother or father (or other adult family member)?" Responses ranged from "never" to "every day." The measure for both years was categorized as high ( $\geq 7$ times a week), moderate ( $2-6$ times a week) and low $(\leq 1$ times per week). These responses were kept separate for the two cycles.

All food and beverage items were derived from the Food Frequency Questionnaire (FFQ) in the HBSC survey. Students were asked how many times they usually eat or drink selected food items in a typical week. Items used for this study were non-SSBs (diet soft drinks and fruit juice), SSBs (soft drinks, sports drinks, energy drinks), fruits and vegetables (fruit, vegetables, dark green vegetables, orange vegetables), game from hunting, sweets and potato chips. There were seven response options ranging from "never" to "more than once a day, every day." The average weekly consumption of each item was calculated by recoding the response categories as: $0=$ "never," $0.25=$ "less than once a week," 1 = "once a week," 3 = " $2-4$ days a week," $5.5=$ "5-6 days a week", 7 = "once a day every day" and "more than once a day, every day." The FFQ has been tested for test re-test reliability and shown to have Spearman's correlations ranging from 0.57 for potato chips to 0.80 for regular soft drinks (Vereecken et al., 2005, 2008; Levin et al., 2012).

Summary items were created for SSBs, fruit and vegetables, and sweets and chips. Responses were coded as above with the exception of "more than once a day, every day," which was coded as 14 . To obtain an overall score for weekly fruit and vegetables and SSB consumption, each item was summed (Vereecken et al., 2008). All consumption items are categorized as low (never and less 
than once a week), moderate (once a week to 6 days a week) or high (once a day every day and more than once a day every day).

Finally, soft drink prices for the provinces were obtained from Statistics Canada. Data on soft drink prices were obtained directly from the statistics bureau of each individual territory. Prices represent an average price from all available communities within the territory.

\section{Statistical Analysis}

Data analyses were conducted in SAS version 9.4 (SAS Institute, Cary, North Carolina, 2012). Descriptive analyses were used to investigate population characteristics and consumption patterns. Analysis was organized according to Nunavut, the three territories combined (i.e., the North), and the provinces (i.e., the South). Rao-Scott chi-square tests were used to test significant differences $(p<0.05)$ between characteristics of youth in the provinces versus the territories. Row frequencies were presented to describe daily or higher SSB consumers by several variables as well as chi-square tests for association $(p<0.05)$. Missing data were investigated for patterns and determined to be missing at random (MAR). The numbers of missing values were reported for each variable. Variables with missing data greater than $50 \%$ were excluded.

\section{RESULTS}

\section{Sample Population and Individual Characteristics}

The total study population consisted of 26078 adolescents in 2010 and 30117 adolescents in 2014. Estimates for overall proportions are within a confidence interval of $\pm 1 \%$. Regional estimates (North, South, and Nunavut) are within $\pm 5 \%$. Table 1 describes the sample characteristics from 2010 and 2014 across the provinces, territories and Nunavut. Students' age ranged from 9 to 19 years. The mean age (SD) for 2010 for girls was 13.3 (1.5) years and 13.4 (1.6) for boys. In 2014, the mean age was 14 (1.4) for girls and 14.0 (1.5) for boys. Grade and sex were evenly distributed across the sample. In 2010, more youth in the territories reported low family affluence as compared to the provinces, and more youth in Nunavut reported being of low affluence than in the territories combined. In terms of BMI, differences varied greatly by region. Obesity and overweight were highest in Nunavut, followed by the territories and lowest in the provinces.

Table 1 also shows the frequency of physical activity and reduced screen time. The majority of youth across regions did not meet the daily 60-minute guidelines for physical activity. There was a significant difference between northern (14.5\%) and southern (16.8\%) regions with respect to physical activity levels, which were lowest in Nunavut. Screen time use was also high across all provinces and territories, including Nunavut.

\section{Community Characteristics}

Home community characteristics are reported for the 2010 cohort only and are described in Table 2. In 2010, adolescents in Nunavut were more likely to live in small communities, as defined by there being less than 500 people living in the $1 \mathrm{~km}$ radius around the school, than those in the provinces. Communities in Nunavut were exclusively fly-in, whereas no provincial communities included in the survey were fly-in. As for the other territories, seven communities were fly-in but accessible to the southern provinces via winter roads, while one community was entirely fly-in. Finally, in terms of soft drink prices, Nunavut had the highest prices at a mean of $\$ 12.08$ per $2 \mathrm{~L}$ bottle. This was followed by the territories, which had a mean price of $\$ 5.07$ per $2 \mathrm{~L}$ bottle and the provinces, which had the lowest prices throughout at a mean of $\$ 2.03$ per $2 \mathrm{~L}$ bottle.

\section{Food Consumption}

Food behaviours in 2010 and 2014 include consumption of fruit and vegetables, eating food from game hunting, sweets and potato chips intake, regularity of weekday breakfasts, and family meals (Table 3). In most cases, significant differences were found between the northern territories and the southern provinces, and patterns were more pronounced for comparisons with Nunavut individually.

In 2010 and 2014, fruit and vegetable consumption by young people was significantly different in the territories compared to the provinces. Young people in the territories consumed fruit and vegetables less often than those in the provinces (74\% in 2010 and $77 \%$ in 2014 consumed these foods once a day or more, compared to $82 \%$ in both years in the provinces). Nunavut students consumed these foods even less often (only 58\% in 2010 and 52\% in 2014 consumed them once a day or more). A similar pattern, in reverse, emerged for consumption of sweets and potato chips: young people in the provinces consumed the least, followed by the territories, then Nunavut. Wild game consumption was also significantly higher in the northern territories, in both 2010 and 2014, than in the provinces and was highest in Nunavut.

\section{Beverage Consumption}

Consumption of non-SSBs (fruit juice and diet soft drinks) and SSBs (soft drinks, energy drinks, and sports drinks) can also be viewed in Table 3. In both 2010 and 2014, youth in Nunavut were more likely to consume fruit juice at least once daily ( $45 \%$ and $43 \%$ respectively) than youth in all territories and the provinces. Diet soft drink consumption was low across all regions in both years, approximately $4 \%$, including Nunavut.

Soft drinks were the most consumed SSB. Rates of daily or greater soft drink consumption in Nunavut were high, $42.7 \%$ in 2014 and $37.8 \%$ in 2010 , compared to the 
TABLE 1. Description of the study population from Nunavut, all three territories combined, and the provinces (number, \%)

\begin{tabular}{|c|c|c|c|c|c|c|c|c|}
\hline & \multicolumn{4}{|c|}{2010} & \multicolumn{4}{|c|}{2014} \\
\hline & $\begin{array}{l}\text { Nunavut } \\
(\mathrm{n}=832)\end{array}$ & $\begin{array}{l}\text { Territories } \\
(\mathrm{n}=3942)\end{array}$ & $\begin{array}{l}\text { Provinces } \\
(\mathrm{n}=22136)\end{array}$ & $p^{1}$ & $\begin{array}{l}\text { Nunavut } \\
(\mathrm{n}=540)\end{array}$ & $\begin{array}{l}\text { Territories } \\
(\mathrm{n}=3625)\end{array}$ & $\begin{array}{l}\text { Provinces } \\
(\mathrm{n}=26492)\end{array}$ & $p^{1}$ \\
\hline \multicolumn{9}{|l|}{ School Grade: } \\
\hline$\leq 6$ & $194(23.3)$ & $798(20.2)$ & 4367 (19.7) & 0.3199 & $120(22.2)$ & $711(19.6)$ & $3916(14.8)$ & $<.0001$ \\
\hline 7 & $175(21.0)$ & $826(21.0)$ & 4379 (19.8) & & 118 (21.9) & $702(19.4)$ & $5126(19.4)$ & \\
\hline 8 & $147(17.7)$ & $770(19.5)$ & $4496(20.3)$ & & $130(24.1)$ & $804(22.2)$ & $5038(19.0)$ & \\
\hline 9 & $188(22.6)$ & 809 (20.5) & $4586(20.7)$ & & $93(17.2)$ & $673(18.6)$ & $6307(23.8)$ & \\
\hline$\geq 10$ & $128(15.4)$ & 739 (18.8) & 4308 (19.5) & & 79 (14.6) & $735(20.3)$ & $6104(23.0)$ & \\
\hline Missing ${ }^{2}$ & 0 & 0 & 0 & & 0 & 0 & 0 & \\
\hline \multicolumn{9}{|l|}{ Sex: } \\
\hline Female & $420(50.9)$ & 1949 (49.7) & $10903(49.3)$ & 0.2263 & $257(48.2)$ & $1816(50.3)$ & $13362(50.7)$ & 0.6757 \\
\hline Male & $406(49.1)$ & 1975 (50.3) & $11220(50.7)$ & & 276 (51.78) & 1792 (49.7) & $12991(49.3)$ & \\
\hline Missing & 6 & 18 & 13 & & 7 & 17 & 138 & \\
\hline \multicolumn{9}{|l|}{ Family affluence: } \\
\hline High & $201(35.0)$ & $2108(62.8)$ & $13595(66.8)$ & $<.0001$ & - & $1623(54.1)$ & $15526(65.1)$ & $<.0001$ \\
\hline Average & $275(47.8)$ & $1078(32.1)$ & $6310(31.0)$ & & - & $1124(37.5)$ & $7756(32.5)$ & \\
\hline Low & 99 (17.2) & $173(5.1)$ & $457(2.2)$ & & - & $253(8.4)$ & $556(2.3)$ & \\
\hline Missing & 257 & 583 & 1773 & & - & 625 & 2653 & \\
\hline \multicolumn{9}{|l|}{ BMI: } \\
\hline Underweight & 15 ( 3.6$)$ & $69(2.6)$ & $560(3.2)$ & $<.0001$ & $4(1.8)$ & $88(3.9)$ & $639(3.4)$ & $<.0001$ \\
\hline Normal & $234(55.9)$ & $1729(66.2)$ & $12412(70.5)$ & & $118(53.9)$ & $1378(62.1)$ & 13096 (69.6) & \\
\hline Overweight & $124(29.6)$ & $565(21.6)$ & $3163(18.0)$ & & $61(27.9)$ & $499(22.5)$ & 3390 (18.0) & \\
\hline Obese & $46(11.0)$ & $249(9.5)$ & $1473(8.4)$ & & $36(16.4)$ & $255(11.5)$ & $1699(9.0)$ & \\
\hline Missing & 413 & 1330 & 4527 & & 321 & 1405 & 7667 & \\
\hline \multicolumn{9}{|l|}{ Physical activity: } \\
\hline 7 days/week & $100(13.1)$ & $487(13.0)$ & 3157 (14.7) & 0.0064 & $62(12.3)$ & $501(14.5)$ & $4321(16.8)$ & 0.0006 \\
\hline$<7$ days/week & $662(86.9)$ & $3265(87.0)$ & $18359(85.3)$ & & $443(87.7)$ & $2964(85.5)$ & $21467(83.2)$ & \\
\hline Missing & 70 & 190 & 620 & & 35 & 160 & 703 & \\
\hline \multicolumn{9}{|l|}{ Screen time: } \\
\hline$\leq 2$ hours/day & 69 (12.1) & $475(14.5)$ & 2231 (11.2) & $<.0001$ & 79 (19.0) & 365 (11.4) & $2005(8.6)$ & $<.0001$ \\
\hline$>2$ hours/day & $503(87.9)$ & $2800(85.5)$ & $17709(88.8)$ & & $337(81.0)$ & $2830(88.6)$ & 21365 (91.4) & \\
\hline Missing & 260 & 667 & 2195 & & 124 & 430 & 3121 & \\
\hline \multicolumn{9}{|c|}{ Grandparents in the home: } \\
\hline Yes & $84(12.0)$ & $323(8.8)$ & $1482(6.9)$ & $<.0001$ & - & $280(9.1)$ & $1762(7.0)$ & $<.0001$ \\
\hline No & $614(88.0)$ & 3337 (91.2) & $19973(93.1)$ & & - & $2794(90.9)$ & $23540(93.0)$ & \\
\hline Missing & 134 & 282 & 680 & & - & 551 & 1189 & \\
\hline \multicolumn{9}{|l|}{ Family structure: } \\
\hline 2 parents & $362(51.9)$ & $2074(56.7)$ & $14430(67.3)$ & $<.0001$ & - & $1814(59.0)$ & $17766(70.2)$ & $<.0001$ \\
\hline Other & $336(48.1)$ & $1585(43.3)$ & $7027(32.7)$ & & - & $1260(41.0)$ & $7536(29.8)$ & \\
\hline Missing & 134 & 283 & 679 & & - & 551 & 1189 & \\
\hline \multicolumn{9}{|l|}{ Teeth brushing: } \\
\hline$\geq$ Once a day & $612(75.6)$ & $3436(88.3)$ & $20719(94.2)$ & $<.0001$ & - & $2855(89.2)$ & $24743(94.4)$ & $<.0001$ \\
\hline$<$ Once a day & $198(24.4)$ & $456(11.7)$ & $1269(5.8)$ & & - & $345(10.8)$ & $1483(5.6)$ & \\
\hline Missing & 22 & 50 & 148 & & - & 425 & 265 & \\
\hline
\end{tabular}

${ }^{1} P$-value for Rao-Scott chi-square test between provinces and territories only.

2 "Missing" indicates the number of respondents for whom data on a characteristic were unavailable. In Nunavut, some data were missing because of the shortened survey administered in this region.

provinces and territories. Similarly, higher rates of sports and energy drinks were seen in Nunavut youth compared to youth in the provinces and territories. Overall for 2010 and 2014, rates of SSB consumption once daily or more were highest among youth from Nunavut (53\% and 55\% respectively), followed by the territories and the provinces. More than half of the Nunavut sample consumed SSBs once a day or more in both years compared to one quarter or less in the provinces.

Characteristics of daily SSB consumers are described in Table 4. Significant associations with high SSB consumption were found for all variables tested in the territories combined and the provinces. In Nunavut, however, significant associations with SSB consumption were found only for school grade, game consumption, and screen time. In the North and South of Canada, high consumers were more likely to be male, in older grades, from non-nuclear families, to have low socio-economic status, and to live with their grandparents. They were also more likely to eat high amounts of game and low amounts of fruits and vegetables and to consume breakfast and participate in family meals less than five days a week.

\section{DISCUSSION}

Overall, very high rates of once daily or more SSB consumption were found among young people in Nunavut when compared to youth in other regions. For all three regions, significant bivariate associations were found 
TABLE 2. Home community characteristics of youth sampled from Nunavut, the northern territories, and the provinces in 2010 (number, \%).

\begin{tabular}{lccc}
\hline \hline & Nunavut $(\mathrm{n}=832)$ & Territories $(\mathrm{n}=3942)$ & Provinces $(\mathrm{n}=22136)$ \\
\hline Community population': & & & \\
$\quad$ Small $(<500)$ & $199(23.9)$ & $566(14.4)$ & $1286(5.8)$ \\
$\quad$ Medium $(500-3000)$ & $633(76.1)$ & $2273(57.7)$ & $7205(32.6)$ \\
$\quad$ Large $(>3000)$ & 0 & $1103(28.0)$ & $13645(61.6)$ \\
Road access: & 0 & $2909(73.8)$ & $22136(100)$ \\
$\quad$ Permanent & $832(100)$ & $904(22.9)$ & 0 \\
$\quad$ Fly-in & 0 & $129(3.3)$ & 0 \\
$\quad$ Winter road & 0 & $93(2.4)$ & $22136(100)$ \\
Soft drink price: & $832(100)$ & $3849(97.6)$ & 0 \\
$\quad \$ 2.03 / 2 \mathrm{~L}$ & & & \\
\hline \$2.03/2L & & & \\
\hline \hline
\end{tabular}

${ }^{1}$ Community population represents the population living in the $1 \mathrm{~km}$ buffer area around the school.

between high SSB consumption and game consumption, grade in school, and screen time. Results also show that while bivariate associations exist between high SSB consumption and predicting variables (including SES, sex, and family meals) in the provinces and the territories, these associations do not hold in the context of Nunavut.

Dietary behaviours have changed dramatically in Nunavut over the past 50 years. One explanation for the rise in SSB consumption may be associated with Nunavut's recent colonization. For hundreds or even thousands of years, the traditional Inuit diet included nutrient-dense foods, such as wild game, marine mammals, fish, birds, seasonal roots, stems, tubers, and wild berries (Kuhnlein and Receveur, 2007; Mead et al., 2010). Colonization and settlement resulted in a devaluing of Inuit traditional practices and a rapid change from nomadic life (Horvath, 1972). Evidence indicates that with the decline in consumption of traditional food in Nunavut, there has been a corresponding increase and desire for store-bought foods, especially among children (Wein et al., 1996; Kuhnlein et al., 2004; Hopping et al., 2010; Sheehy et al., 2013). Studies have found, for example, that more than $40 \%$ of children's daily energy is derived from non-nutrient, energy-dense, store-bought foods (Kuhnlein et al., 2004). With a reduction in hunting and gathering and thus in the availability of country foods, there has been some loss of knowledge about traditional food practices and an increasing value placed on store-bought foods. Inuit - in particular, younger generations - are commonly relying on store-bought meal alternatives and beverages such as SSBs (Chan et al., 2006; Mead et al., 2010).

Other social factors may also be influencing SSB consumption in the North. Previous studies have shown that family meals are positively associated with fruit and vegetable intake and negatively associated with soft drink consumption (Neumark-Sztainer et al., 2003). The current study partially supports these findings. For the provinces and territories combined, although not specifically for Nunavut, there was a negative association between the number of family meals per week and daily SSB consumption. One possible explanation for the lack of association found in Nunavut could be the effects of overcrowding. Many families in Nunavut live in crowded, multi-generational homes, which may result in more "family meals" because the family must eat together out of necessity (Egeland et al., 2010a).

A growing reliance on, and enjoyment of, convenience foods among both parents and children may be one explanation for the high rates of SSB consumption found in Nunavut. Another explanation might be related to family structure. Previous research has shown that adolescents in nuclear households (i.e., with two parents) are less likely to consume junk food such as SSBs than adolescents in nonnuclear households (Ambrosini et al., 2009; Stewart and Menning, 2009). The current study shows that adolescents in nuclear families are less likely to consume SSBs on a daily basis than adolescents living in non-nuclear families. There could be several reasons for this. One reason found in southern Canadian communities is that single parents who are working long hours or have multiple jobs rely on quick and convenient foods to feed their families (Patrick and Nicklas, 2005). Adolescents in one-parent households may also have less supervision and more autonomy in their food and beverage choices, which could result in higher consumption of preferred sugary foods. These relationships may differ in the northern setting because of differences in housing, employment, and culture. There is a general gap in research about how family structure specifically in the North may be affecting SSB consumption.

One other aspect of family structure associated with SSB consumption is the presence of grandparents in the home. Although it may seem that having an additional adult or parental figure would foster healthier eating habits, this has not always been shown to be the case in previous studies. Grandparents have been shown to provide children with treats such as SSBs regardless of parental approval (Hoare et al., 2014). Overall, we found that adolescents who were living with grandparents were more likely to consume SSBs than those who did not. Interestingly, in the context of Nunavut, this difference was less pronounced. It is possible that the lack of association between grandparents and SSB consumption found in Nunavut may be due to 


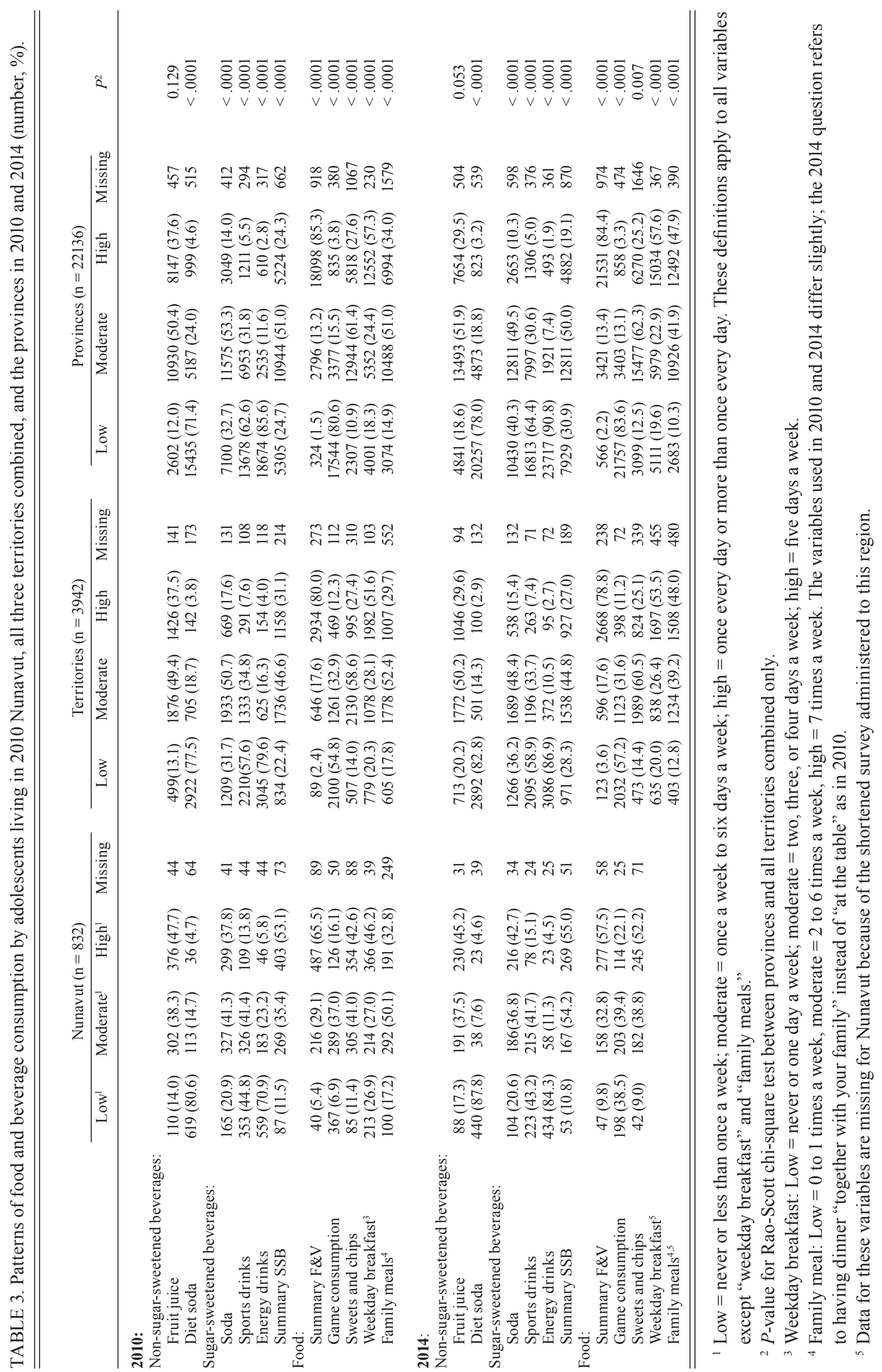


TABLE 4. Description of adolescents who consumed SSBs once a day or more in 2010 in Nunavut, all three territories combined, and the provinces.

\begin{tabular}{|c|c|c|c|c|c|c|}
\hline & \multicolumn{2}{|c|}{ Nunavut } & \multicolumn{2}{|c|}{ Territories } & \multicolumn{2}{|c|}{ Provinces } \\
\hline & $\begin{array}{c}\% \geq \text { Daily SSB } \\
\text { consumption }\end{array}$ & $p$-value ${ }^{1}$ & $\begin{array}{c}\% \geq \text { Daily SSB } \\
\text { consumption }\end{array}$ & $p$-value ${ }^{1}$ & $\begin{array}{c}\% \geq \text { Daily SSB } \\
\text { consumption }\end{array}$ & $p$-value \\
\hline Sex: & & 0.0903 & & $<.0001$ & & $<.0001$ \\
\hline Male & 56.2 & & 36.1 & & 31.4 & \\
\hline Female & 50 & & 26 & & 17.5 & \\
\hline School grade: & & $<.0001$ & & $<.0001$ & & $<.0001$ \\
\hline 6 to 8 & 46 & & 28.2 & & 22.8 & \\
\hline 9 and 10 & 64.4 & & 35.4 & & 26.6 & \\
\hline Game consumption: & & $<.0001$ & & $<.0001$ & & $<.0001$ \\
\hline High & 65.8 & & 51.6 & & 53.5 & \\
\hline Moderate & 59.7 & & 34.7 & & 34.7 & \\
\hline Low & 43.5 & & 24.5 & & 21 & \\
\hline Family meals: & & 0.3677 & & 0.0181 & & $<.0001$ \\
\hline 7 days/week & 52.7 & & 26 & & 20.9 & \\
\hline$<7$ days & 48.6 & & 30.1 & & 25.2 & \\
\hline Family affluence: & & 0.3219 & & 0.0007 & & $<.0001$ \\
\hline High & 50.8 & & 27.1 & & 23.1 & \\
\hline Average & 55 & & 31.4 & & 24 & \\
\hline Low & 46.4 & & 38.9 & & 32.4 & \\
\hline Grandparents: & & 0.6045 & & 0.0017 & & $<.0001$ \\
\hline Yes & 55.7 & & 38.1 & & 31.3 & \\
\hline No & 52.6 & & 29.5 & & 23.5 & \\
\hline Physical activity: & & 0.064 & & 0.0004 & & $<.0001$ \\
\hline 7 days/week & 62 & & 38.1 & & 34.6 & \\
\hline$<7$ days/week & 51.6 & & 29.9 & & 22.7 & \\
\hline Screen time: & & $<.0001$ & & $<.0001$ & & $<.0001$ \\
\hline$\leq 2$ hours/day & 27.3 & & 12.2 & & 13.3 & \\
\hline$>2$ hours/day & 55.5 & & 32.2 & & 24.9 & \\
\hline Weekday breakfast: & & 0.1529 & & $<.0001$ & & $<.0001$ \\
\hline 5 days/week & 49.6 & & 25.3 & & 19.5 & \\
\hline$<5$ days & 54.8 & & 36.7 & & 30.7 & \\
\hline Fruit and vegetables: & & 0.9493 & & $<.0001$ & & $<.0001$ \\
\hline High & 54.2 & & 29.3 & & 22.5 & \\
\hline Moderate & 52.9 & & 37.3 & & 33.7 & \\
\hline Low & 53.8 & & 42.5 & & 47.6 & \\
\hline Family structure: & & 0.1167 & & $<.0001$ & & $<.0001$ \\
\hline 2 parents & 50 & & 26.7 & & 22 & \\
\hline Other & 56.1 & & 34.9 & & 28.3 & \\
\hline
\end{tabular}

${ }^{1} P$-value for Rao-Scott chi-square tests for significant difference between the levels of each variable $(p<0.05)$.

the strong influence that elders play in Inuit communities. For example, elders often pass on essential cultural information, such as the importance of hunting and the consumption of traditional foods, which could result in less SSB consumption (Mead et al., 2010). Further research would do well to investigate the potential influence of elders and grandparents on SSB consumption among Inuit youth.

Another common explanation for SSB consumption is socio-economic status-lower SSB consumption, for example, has been shown to be associated with higher SES (Mazarello Paes et al., 2015). The current study is no exception. Family affluence level was inversely associated with SSB consumption level in the provinces and territories. Interestingly, although family affluence was lower in Nunavut than in the other regions $(17.2 \%$ reporting low family affluence vs. $2.2 \%$ in the provinces), there was no significant association between SES and SSB consumption there. One explanation may be that because soft drink prices are higher in Nunavut than in the South, they may be less accessible to those of lower family affluence. Another explanation is that the Family Affluence Scale, as a measure of SES, may not differentiate affluence levels well among young people in Nunavut. This could be because the Family Affluence Scale items, such as international vacations, or number of cars, vans or trucks may only differentiate the very wealthy from the majority and not differentiate across the full SES gradient. Many families do not purchase cars regardless of ability to pay, for example, as they use allterrain vehicles and snow machines more commonly in some communities. Even well-off families may not choose to travel internationally but could be traveling across the North, or to other Canadian destinations. Failure to be able to measure a full SES gradient in Nunavut may explain why SSB consumption is not associated with family affluence in this region.

This study has both strengths and limitations. A major strength is the study's large sample size, which provides adequate power, especially in Nunavut, where previous sample sizes have been relatively small and where the current study is territorially representative. Further, this study provides essential information on SSB consumption patterns, especially in Nunavut, where patterns have not 
been previously documented at a territorial level. This study was undertaken with guidance from northern stakeholders and addresses an important public health concern for Northerners and for all Canadians.

The study also has several limitations. The 2014 cycle of the HBSC is lacking some variables for Nunavut, including questions regarding the Family Affluence Scale and frequency of family dinners, because only a shortened questionnaire was presented to the Nunavut students in 2014. For this reason, bivariate associations used data only from the 2010 cycle of the HBSC and this reduced the available sample size. Another limitation is the fact that we do not know the exact volume of SSB or other food and beverages consumed at each instance. Further, the category of "more than once a day" does not quantify the amount consumed in one day; for example, a student consuming two cans of soft drink a day and a student consuming 10 cans a day would be placed in the same category. This is problematic because there could be differences between individuals within this high consumer category. Furthermore, the item for "fruit juice" may be misclassified, because some youth may consider juice cocktails or crystals as fruit juice instead of a sugarsweetened beverage. The food frequency questionnaire also does not include other beverages, such as milk, water, or alcohol, all of which would have been helpful to include.

\section{CONCLUSION}

The current study presents data on SSB consumption among adolescents in Nunavut, the territories combined, and the provinces. The proportion of adolescents in Nunavut who report consuming high amounts of SSBs is more than double that of their counterparts in the provinces. Another important finding is that Nunavut has high consumption levels of other energy-dense food, particularly when compared to the levels reported for students in the other territories and the provinces. Overall these results present empirical, population-level data that help confirm important dietary issues in the North and in Nunavut and could be used to advocate for and inform future nutrition and health promotion interventions.

\section{ACKNOWLEDGEMENTS}

This study received ethical clearance from the Queen's University Health Sciences and Affiliated Teaching Hospitals Research Ethics Board (\#6016256), and the national Health Behaviour in School-aged Children (HBSC) study has approval from both the Queen's University General Research Ethics Board (File \#GMISC-062-13) and the Public Health Agency of Canada/ Health Canada. The authors would also like to acknowledge the HBSC study for permission to use the data and operating funding received from the Canadian Institutes of Health Research. The HBSC study is funded through the Public Health Agency of
Canada and administered by the Social Program Evaluation Group at Queen's University. We thank the community of Arviat, Nunavut, for hosting author L. Davis during her preliminary studies. We also thank Shirley Tagalik (Aqqiumavvik Society, Arviat) and Government of Nunavut stakeholders in Iqaluit for their input and continued interest in this project.

\section{REFERENCES}

Ambrosini, G.L., Oddy, W.H., Robinson, M., O’Sullivan, T.A., Hands, B.P., de Klerk, N.H., Silburn, S.R., et al. 2009. Adolescent dietary patterns are associated with lifestyle and family psycho-social factors. Public Health Nutrition 12(10):1807-1815.

https://doi.org/10.1017/S1368980008004618

Bernabé, E., Vehkalahti, M.M., Shelham, A., Aromaa, A., and Suominen, A.L. 2014. Sugar-sweetened beverages and dental caries in adults: A 4-year prospective study. Journal of Dentistry 42(8):952-958.

https://10.1016/j.jdent.2014.04.011

Boyce, W., Torsheim, T., Currie, C., and Zambon, A. 2006. The Family Affluence Scale as a measure of national wealth: Validation of an adolescent self-report measure. Social Indicators Research 78(3):473-487.

https://doi.org/10.1007/s11205-005-1607-6

Canadian Society for Exercise Physiology. 2012a. Canadian physical activity guidelines.

http://www.csep.ca/CMFiles/Guidelines/bcfiles/BC_CSEP PAGuidelines_youth_en.pdf

_ 2012b. Canadian sedentary behaviour guidelines. http://www.csep.ca/CMFiles/Guidelines/CanadianSedentary GuidelinesStatements_E_2012.pdf

Chan, H.M., Fediuk, K., Hamilton, S., Rostas, L., Caughey, A., Kuhnlein, H., and Loring, E. 2006. Food security in Nunavut, Canada: Barriers and recommendations. International Journal of Circumpolar Health 65(5):416-431.

https://doi.org/10.3402/ijch.v65i5.18132

Currie, C., Molcho, M., Boyce, W., Holstein, B., Torsheim, T., and Richter, M. 2008. Researching health inequalities in adolescents: The development of the Health Behaviour in School-Aged Children (HBSC) Family Affluence Scale. Social Science and Medicine 66(6):1429-1436. https://doi.org/10.1016/j.socscimed.2007.11.024

Danyliw, A.D., Vatanparast, H., Nikpartow, N., and Whiting, S.J. 2012. Beverage patterns among Canadian children and relationship to overweight and obesity. Applied Physiology, Nutrition, and Metabolism 37(5):900-906. https://doi.org/10.1139/h2012-074

Egeland, G.M., Faraj, N., and Osborne, G. 2010a. Cultural, socioeconomic, and health indicators among Inuit preschoolers: Nunavut Inuit Child Health Survey, 2007-2008. Rural and Remote Health 10: 1365.

http://www.rrh.org.au/articles/subviewnew.asp?Article ID $=1365$ 
Egeland, G.M., Pacey, A., Cao, Z., and Sobol, I. 2010b. Food insecurity among Inuit preschoolers: Nunavut Inuit Child Health Survey, 2007-2008. Canadian Medical Association Journal 182(3):243-248.

https://doi.org/10.1503/cmaj.091297

Garriguet, D. 2008a. Beverage consumption of Canadian adults. Health Reports 19(4). Catalogue no. 82-003-XPE. Ottawa: Statistics Canada.

http://www.statcan.gc.ca/pub/82-003-x/2008004/article/ 6500821-eng.pdf

- 2008b. Beverage consumption of children and teens. Health Reports 19(4). Catalogue no. 82-003-XPE. Ottawa: Statistics Canada.

http://www.statcan.gc.ca/pub/82-003-x/2008004/article/ 6500820 -eng.pdf

Gates, A., Skinner, K., and Gates, M. 2014. The diets of schoolaged Aboriginal youths in Canada: A systematic review of the literature. Journal of Human Nutrition and Dietetics 28(3):246-261.

https://doi.org/10.1111/jhn.12246

Government of Nunavut. 2015. Nunavut quick facts. Iqaluit: Government of Nunavut. http://www.stats.gov.nu.ca/en/home.aspx

Health Canada. 2007. Canadian Community Health Survey, Cycle 2.2, Nutrition (2004): Income-related food security in Canada. Ottawa: Health Canada.

http://www.hc-sc.gc.ca/fn-an/surveill/nutrition/commun/ income_food_sec-sec_alim-eng.php

- 2010. Canadian Health Measures Survey (CHMS): Oral health statistics 2007-2009. Ottawa: Health Canada.

http://www.hc-sc.gc.ca/hl-vs/pubs/oral-bucco/fact-fiche-oralbucco-stat-eng.php

Hoare, A., Virgo-Milton, M., Boak, R., Gold, L., Waters, E., Gussy, M., Calache, H., Smith, M., and de Silva, A.M. 2014. A qualitative study of the factors that influence mothers when choosing drinks for their young children. BMC Research Notes 7:430. https://doi.org/10.1186/1756-0500-7-430

Hopping, B.N., Erber, E., Mead, E., Sheehy, T., Roache, C., and Sharma, S. 2010. Socioeconomic indicators and frequency of traditional food, junk food, and fruit and vegetable consumption amongst Inuit adults in the Canadian Arctic. Journal of Human Nutrition and Dietetics 23(s1):51-58. https://doi.org/10.1111/j.1365-277X.2010.01100.x

Horvath, R.J. 1972. A definition of colonialism. Current Anthropology 13(1):45-57.

Houde, G., Gagnon, P.F., and St-Germain, M. 1991. A descriptive study of early caries and oral health habits of Inuit preschoolers: Preliminary results. Arctic Medical Research Suppl:683-684. https://doi.org/10.1016/j.physbeh.2010.01.036

Hu, F.B., and Malik, V.S. 2010. Sugar-sweetened beverages and risk of obesity and type 2 diabetes: Epidemiologic evidence. Physiology and Behavior 100(1):47-54 https://doi.org/10.1016/j.physbeh.2010.01.036
Kuhnlein, H.V., and Receveur, O. 2007. Local cultural animal food contributes high levels of nutrients for Arctic Canadian Indigenous adults and children. The Journal of Nutrition 137(4): $1110-1114$.

Kuhnlein, H.V., Receveur, O., Soueida, R., and Egeland, G.M. 2004. Arctic Indigenous peoples experience the nutrition transition with changing dietary patterns and obesity. The Journal of Nutrition 134(6):1447-1453.

Lawrence, H.P., Romanetz, M., Rutherford, L., Cappel, L., Binguis, D., and Rogers, J.B. 2004. Oral health of Aboriginal preschool children in northern Ontario. PROBE 38(4):172-190. http://www.caphd.ca/sites/default/files/Aboriginal_Preschool. pdf

Levin, K.A., Kirby, J., Currie, C., and Inchley, J. 2012. Trends in adolescent eating behaviour: A multilevel cross-sectional study of 11-15 year olds in Scotland, 2002-2010. Journal of Public Health 34(4):523-531.

https://doi.org/10.1093/pubmed/fds021

Lobstein, T. 2014. WHO reducing consumption of sugar-sweetened beverages to reduce the risk of childhood overweight and obesity. eLENA: e-Library of Evidence for Nutrition Actions. http://www.who.int/elena/bbc/ssbs_childhood_obesity/en/

Malik, V.S., Pan, A., Willett, W.C., and Hu, F.B. 2013. Sugarsweetened beverages and weight gain in children and adults: A systematic review and meta-analysis. The American Journal of Clinical Nutrition 98(4):1084-1102.

https://doi.org/10.3945/ajcn.113.058362

Mazarello Paes, V., Hesketh, K., O’Malley, C., Moore, H., Summerbell, C., Griffin, S., van Sluijs, E.M.F., Ong, K.K., and Lakshman, R. 2015. Determinants of sugar-sweetened beverage consumption in young children: A systematic review. Obesity Reviews 16(11):903-913.

https://doi.org/10.1111/obr.12310

Mead, E., Gittelsohn, J., Kratzmann, M., Roache, C., and Sharma, S. 2010. Impact of the changing food environment on dietary practices of an Inuit population in Arctic Canada. Journal of Human Nutrition and Dietetics 23(s1):18-26. https://doi.org/10.1111/j.1365-277X.2010.01102.x

Neumark-Sztainer, D., Hannan, P.J., Story, M., Croll, J., and Perry, C. 2003. Family meal patterns: Associations with sociodemographic characteristics and improved dietary intake among adolescents. Journal of the Academy of Nutrition and Dietetics 103(3):317-322.

https://doi.org/10.1053/jada.2003.50048

Nunavut Bureau of Statistics. 2011. Population data. http://www.stats.gov.nu.ca/en/Population.aspx

_. 2015. Nunavut food price survey. http://www.stats.gov.nu.ca/en/Economic\%20prices.aspx

Pacey, A., Nancarrow, T., and Egeland, G. 2010. Prevalence and risk factors for parental-reported oral health of Inuit preschoolers: Nunavut Inuit Child Health Survey, 2007-2008. Rural and Remote Health 10: 1368.

http://www.rrh.org.au/articles/subviewnew.asp?Article $\mathrm{ID}=1368 \# 2$ 
Patrick, H., and Nicklas, T.A. 2005. A review of family and social determinants of children's eating patterns and diet quality. Journal of the American College of Nutrition 24(2):83-92 https://doi.org/10.1080/07315724.2005.10719448

Prochaska, J.J., Sallis, J.F., and Long, B. 2001. A physical activity screening measure for use with adolescents in primary care. Archives of Pediatrics and Adolescent Medicine 155(5):554-559. https://doi.org/10.1001/archpedi.155.5.554

Public Health Agency of Canada. 2011. Obesity in Canada: A Joint Report from the Public Health Agency of Canada and the Canadian Institute for Health Information. Ottawa: Public Health Agency of Canada.

http://www.phac-aspc.gc.ca/hp-ps/hl-mvs/oic-oac/index-eng. php

Schmitz, K.H., Harnack, L., Fulton, J.E., Jacobs, D.R., Jr., Gao, S., Lytle, L.A., and Van Coevering, P. 2004. Reliability and validity of a brief questionnaire to assess television viewing and computer use by middle school children. Journal of School Health 74(9):370-377.

https://doi.org/10.1111/j.1746-1561.2004.tb06632.x

Schnohr, C.W., Kreiner, S., Due, E.P., Currie, C., Boyce, W., and Diderichsen, F. 2008. Differential item functioning of a Family Affluence Scale: Validation study on data from HBSC 2001/02. Social Indicators Research 89(1):79-95. https://doi.org/10.1007/s11205-007-9221-4

Schroth, R.J., Harrison, R.L., and Moffatt, M.E.K. 2009. Oral health of Indigenous children and the influence of early childhood caries on childhood health and well-being. Pediatric Clinics of North America 56(6):1481 - 1499. https://doi.org/10.1016/j.pcl.2009.09.010

Sheehy, T., Roache, C., and Sharma, S. 2013. Eating habits of a population undergoing a rapid dietary transition: Portion sizes of traditional and non-traditional foods and beverages consumed by Inuit adults in Nunavut, Canada. Nutrition Journal 12: $70.11 \mathrm{p}$. https://doi.org/10.1186/1475-2891-12-70

Statistics Canada. 2011. Aboriginal peoples in Canada: First Nations People, Métis and Inuit. Ottawa: Statistics Canada. http://www12.statcan.gc.ca/nhs-enm/2011/as-sa/99-011-x/99011-x2011001-eng.cfm
2015. Food and other selected items, average retail prices (Prices). Ottawa: Statistics Canada.

http://www.statcan.gc.ca/tables-tableaux/sum-som/101/cst01/ econ155a-eng.htm

- 2016. Labour force characteristics, seasonally adjusted, by province (monthly) (Newfoundland and Labrador, Prince Edward Island, Nova Scotia, New Brunswick).

http://www.statcan.gc.ca/tables-tableaux/sum-som/101/cst01/ lfss01a-eng.htm

Stewart, S.D., and Menning, C.L. 2009. Family structure, nonresident father involvement, and adolescent eating patterns. Journal of Adolescent Health 45(2):193-201.

Te Morenga, L., Mallard, S., and Mann, J. 2013. Dietary sugars and body weight: Systematic review and meta-analyses of randomised controlled trials and cohort studies. BMJ 346: e7492.

https://doi.org/10.1136/bmj.e7492

Vartanian, L.R., Schwartz, M.B., and Brownell, K.D. 2007. Effects of soft drink consumption on nutrition and health: A systematic review and meta-analysis. American Journal of Public Health 97(4):667-675.

https://doi.org/10.2105/AJPH.2005.083782

Vereecken, C.A., De Henauw, S., and Maes, L. 2005. Adolescents' food habits: Results of the Health Behaviour in School-aged Children Survey. British Journal of Nutrition 94(3):423-431. https://oi.org/10.1079/BJN20051513

Vereecken, C.A., Rossi, S., Giacchi, M.V., and Maes, L. 2008. Comparison of a short food-frequency questionnaire and derived indices with a seven-day diet record in Belgian and Italian children. International Journal of Public Health 53(6):297-305. https://doi.org/10.1007/s00038-008-7101-6

Wein, E.E., Freeman, M.M.R., and Makus, J.C. 1996. Use of and preference for traditional foods among the Belcher Island Inuit. Arctic 49(3):256-264. https://oi.org/10.14430/arctic1201

WHO (World Health Organization). 2015. BMI-for-age (5-19 years). http://www.who.int/growthref/who2007_bmi_for_age/en/ 